\title{
Spatial and temporal distribution of phytoplankton in Perak Estuary, Malaysia, during monsoon season
}

\begin{abstract}
Phytoplankton forms the essential base of the aquatic food web and plays a major role in aquatic productivity and ecosystem health. In the estuary and coastal waters, one of the major factors that controls phytoplankton community structure is the salinity changes along the river-sea continuum. The study was conducted to determine spatial and temporal distribution of phytoplankton along the salinity gradient in Perak river estuarine system during the northeast monsoon from November 2009 to February 2010. Four stations were established along the salinity gradient, from upstream where the salinity was $0.0 \mathrm{ppt}$ to the marine area with salinity values of more than 25.0 ppt. The phytoplankton comprised of six main families namely, Bacillariophyceae (diatoms), Chlorophyceae (green algae), Cyanobacteria (bluegreen algae), Chrysophyceae (golden-brown algae), Euglenophyceae (euglenoids) and Pyrrophyceae (dinoflagellates). A total of 93 species of phytoplankton were recorded from all the stations throughout the season, with green algae and diatoms dominating the upstream and the marine areas, respectively. On the other hand, the estuarine stations were dominated by both green algae and diatoms. The marine station had the highest $(\mathrm{p}<0.05)$ species density during the monsoon season compared to the other stations with a mean total density of $190.6 \pm 27.4$ cells $\mathrm{mL}-1$, whereas, the lowest $(\mathrm{p}<0.05)$ density $(73.8 \pm 11$ cells $\mathrm{mL}-1)$ was observed in the upstream station. Multidimensional scaling analysis based on the phytoplankton densities revealed two distinct groups. The first group consisted of the phytoplankton from the marine station, whereas, the other group consisted of the phytoplankton from the estuarine and upstream stations. In general phytoplankton distribution in Perak estuary was more similar to the freshwater rather than the marine plankton community due to a large flow of freshwater into the estuary during the northeast monsoon. This study revealed that salinity was an important factor in determining the phytoplankton distribution in this tropical ecotone.
\end{abstract}

Keyword: Monsoon season; Phytoplankton distribution; Salinity gradient; Species diversity; Tropical estuarine ecosystem. 